\title{
Towards a multi-stakeholder-driven model for excellence in higher education curriculum development
}

\author{
M. H. Meyer \\ Department of Human Resource Management \\ University of Johannesburg \\ Auckland Park \\ e-mail:mhmeyer@mweb.co.za
}

\author{
M. J. Bushney \\ Department of Human Resource Management \\ University of South Africa \\ South Africa \\ e-mail:mbushney@unisa.ac.za
}

\begin{abstract}
A multi-stakeholder-driven model for excellence in higher education curriculum development has been developed. It is based on the assumption that current efforts to curriculum development take place within a framework of limited stakeholder consultation. A total of 18 multiple stakeholders are identified, including learners, alumni, government, local and international universities, research institutions, SAQA structures and consultants.

The model is further based on significant NQF and OBE alignment of all learning programmes within a multiple stakeholder framework, thereby ensuring that the need of all stakeholders are firmly embedded in curriculum development. Additionally, the principles of learner empowerment, employability, transparency and world-class quality form the foundation of this strategic-driven model for curriculum development. Six phases are postulated with stakeholder engagement during all phases. Three broad areas of quality planning, quality management system implementation and quality review are followed throughout the process. The result is the achievement of excellence in higher education.
\end{abstract}

\section{INTRODUCTION}

The search for stakeholder participation in the post-apartheid era in higher education was firmly laid by the Report of the Council on Higher Education (CHE) in 2000 (Bitzer 2006). According to Jita $(2006,924)$ the processes of stakeholder participation in the higher education quality assurance (HEQA) system have been rather limited and poorly conceptualized. The author argues that there has been no attempt to theorize and/or explain in more detail the role of stakeholders (and/or stakeholder 
participation) in the South African HEQA processes and systems. Although the notion of stakeholder engagement has been well reported in the business literature (Wheeler and Sillanpaa 1997; Savitz and Weber 2006), it has not yet been fully realized in the field of education. Bitzer $(2006,934)$ defines the concept of stakeholders as some person or group who appears to have some form of ownership of, interest in and responsibility for something of value. For the purpose of this current article it appears that stakeholders consist of all relevant parties expecting value from higher education.

In response to the argument of Jita $(2006,924)$ this article attempts to propose a possible multi-stakeholder-driven model for excellence in higher education curriculum development. Although the model is yet to be tested empirically in a follow-up article involving the relevant stakeholders, its potential implications for and advantages to higher education curriculum development and the quality assurance (QA) processes thereof, are explored in this article.

The notion of excellence has been practiced in the business world since the 1980s. Peters and Waterman $(1982,79)$ address excellence from the perspective of meeting and exceeding customer expectations. In similar vein, Csikszentmihalyi $(2003,147)$ defines excellence as the achievement of an ideal of perfection that draws one to a higher level of performance. According to the South African Excellence Foundation $(2000,3)$ excellence depends on 'a system which ensures, through effective leadership, continuous improvement in the delivery of products and services, and which provides a way of satisfaction and responding to customers'.

Guri $(1986,59)$ asks the question: 'How is educational excellence defined and by whom?' Drawing on the science and practice of business management and the application of quality management systems in the field of education, and higher education in particular, the following aspects constitute excellence in higher education:

- The existence of a well-functioning quality management system (Harvey and Green 1993; Hendel and Lewis 2005);

- Meeting and exceeding customer and market needs (Breier and Mabizela 2008; Csikszentmihalyi 2003; Munson 1994);

- High academic standards (Guri 1986; Hendel and Lewis 2005);

- Meeting and exceeding the quality criteria of external quality bodies (Hendel and Lewis 2005; SAEF 2000);

- Receiving awards for excellence and superior performance (SAEF 2000).

Today's competitive business context has radically altered the structural features of the corporations which, in many universities, learners are being insufficiently trained to lead and manage (Barnett 1992). Thus, the need to reassess traditional models for institutional administration, research and teaching has never been more urgent. Yet, universities have demonstrated a reluctance to stimulate major transformation in 
how they educate learners for the real world of work. Success can only be achieved through a highly-skilled, motivated and globally competitive workforce (Rasool 2006).

Only interdisciplinary faculty collaboration, blending functional concentrations into the total business process, can produce learners who are problem-driven, teamoriented, and appropriately sensitised to the realities of managing global businesses (Prahalad 1992). Hence, a new and more dynamic, yet integrated curriculum development model is required. Teaching and publishing on a new interdisciplinary scale is needed (Barnett 1992).

The academic community in American business schools seems less willing to experiment and innovate (Prahalad 1992). The need for active collaboration between practitioners and academics has never been more pronounced. But the two groups are running the risk of drifting apart, thereby sacrificing an opportunity for building a mutually beneficial symbiotic relationship. There is a mismatch between managerial and academic agendas (Prahalad 1992).

A significant number of courses would be offered that are problem-focused rather than discipline-focused (Barnett 1992). While the majority of universities in South Africa have focused primarily on western approaches to management, the need for a dramatic shift to new and different approaches is critical. For instance, comparing management theory in the East, Eastern Europe, South America and Africa in addition to the traditional western theories may provide a more objective comparison between nations and regions of the entire world. We have used a western orientated system while our problems in South Africa and the rest of Africa are drastically different (Birkin 2006). An inclination toward forming partnerships with individuals from other countries and ethnic groups would result from the pedagogical structure of the programme so that, whereas national patriotism would not diminish, a global citizen mind-set would be fostered (Barnett 1992). Excellence also requires more visiting academics from overseas universities (Barnett 1992).

Partners from business should also participate regularly (Barnett 1992). In essence, stakeholders should be identified and their inputs actively utilized to create excellence in higher education.

Birkin (2006) poses a number of thought provoking and provocative questions:

- Why do we continue to accept inadequate and inappropriate models and programmes?

- Why have we failed to use very much better examples that are highly relevant and appropriate for our needs?

- Why have the business schools and the NQF creators not wakened up to this fact?

- Why have we failed to learn from South East Asia, from China and Japan in particular, from international management, and from the US?

- Why do we continue to use thirty year old models? 
As higher education academics we must examine our role in allowing the conditions that gave rise to unethical behaviour and ask what changes in our research and academic programmes are needed to ensure that the next generation of practitioners and academics do not allow similar scandals to emerge (Kochan 2002). We can no longer afford to perpetuate the continuation of academic programmes that do not meet quality requirements based on the needs of industry. Our educational institutions are simply not responding in a proactive and transformative way to providing high-quality, accessible and affordable programmes that contribute to the national challenge decisively (Rasool 2006).

Recently, the deputy president of South Africa, Phumzile Mlambo-Ngcuka stressed the importance of aligning curricula with the economy's requirements so graduates were employable immediately after completing their studies (Khanyile 2007).

Given the low throughput rates, national skills shortages and concerns about academic quality as outlined by Breier and Mabizela $(2008,278)$, a multi-stakeholderdriven model has been developed. The aim of the model is to identify all the relevant stakeholders and to ensure that all phases of the curriculum development process are infused with the typical phases of a quality management approach.

The model has been conceptualized based on extensive liaison with representatives of all 18 identified stakeholders over a period of three years. Furthermore, the preliminary model was reviewed by 19 academics from seven universities in South Africa in August 2007. All academics consulted agreed with all the phases and elements of the model. They collectively expressed the view that the application of the model will most certainly make a contribution towards the achievement of excellence in higher education curriculum development. The only drawback of the model identified is the limited time and resources available to sufficiently engage with all relevant stakeholders, especially in view of the tight time constraints imposed by major curriculum development efforts.

The model for excellence in higher education curriculum development is based on the assumption that current efforts to curriculum development take place within a framework of limited stakeholder consultation (Bitzer 2006; Jita 2006). Some emphasis is placed on liaising with a selected few employers, professional associations and other universities. The new multi-stakeholder-driven model (see Figure 1) suggests the need for active stakeholder engagement as part of curriculum development. A total of 18 multiple stakeholders have been identified, including learners, alumni, government, local and international universities, research institutions, SAQA structures and consultants.

\section{PHASES OF THE MODEL}

The multi-stakeholder-driven model consists of three phases aligned to the planning and implementation of a quality management system for a learning programme. The phases and stages constituting the model are: 

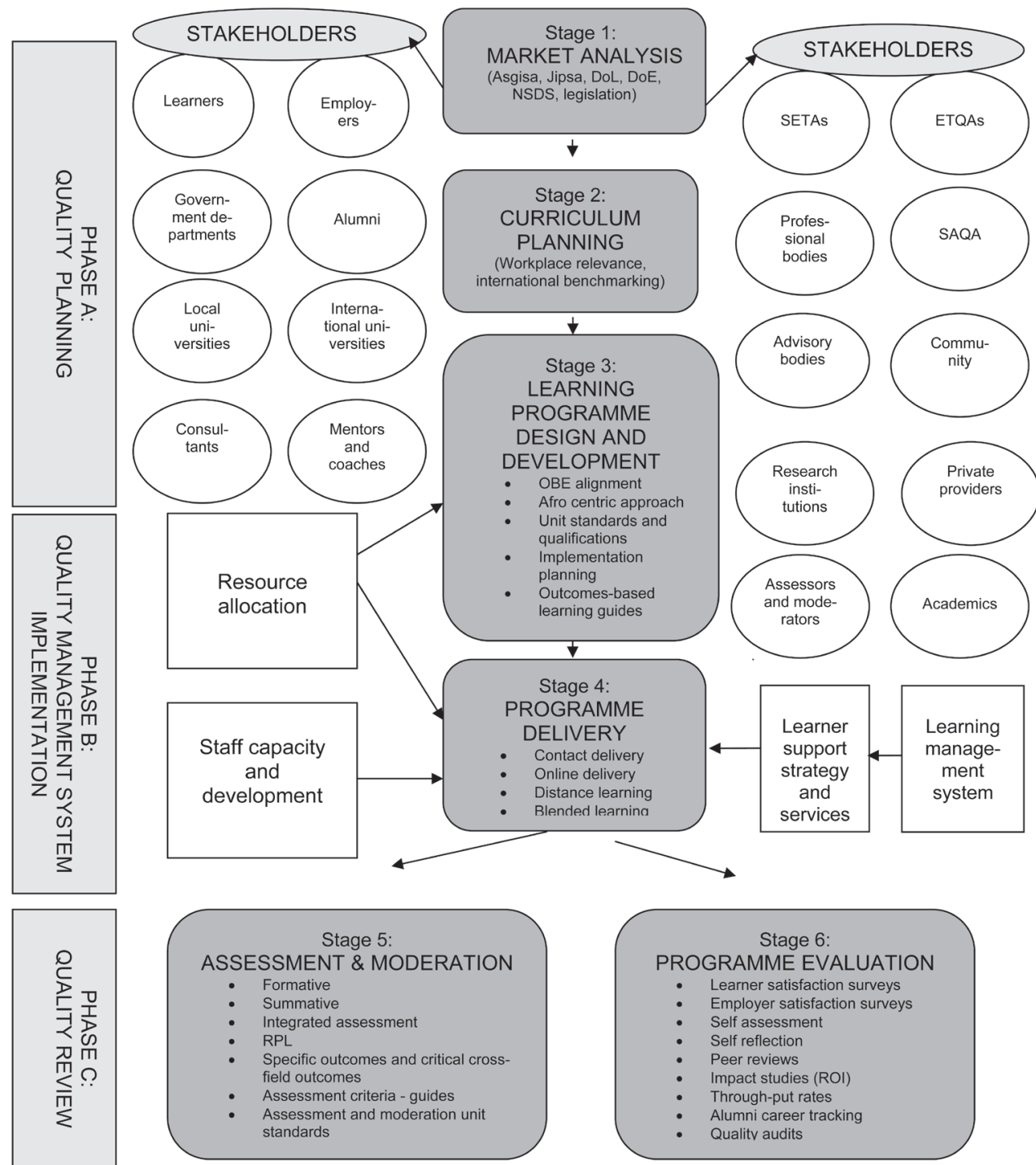

Stage 3

LEARNING

PROGRAMME

DESIGN AND

DEVELOPMENT

- OBE alignment

Afro centric approach Unit standards and qualifications

Implementation

planning

Outcomes-based learning guides
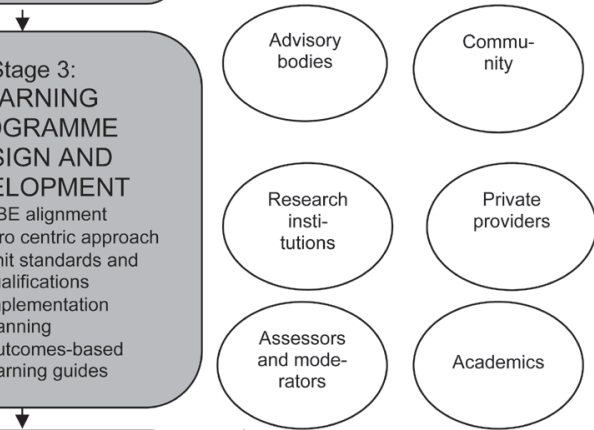

tage 4: PROGRAMME DELIVERY

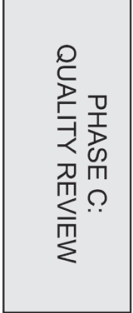

Contact delivery

Online delivery

Distance learning
Blended learnina
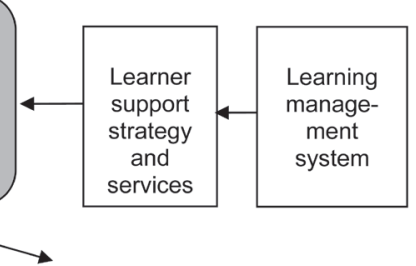

Figure 1: Multiple-stakeholder-driven model for excellence in higher education curriculum development

- Phase A covers all the planning pertaining to curriculum development.

- Phase B deals with the implementation of the quality management system when the learning progamme is delivered.

- Phase $\mathrm{C}$ consists of the process of conducting a quality review to evaluate whether the curriculum meets the quality standards set out to be achieved. 


\section{Phase A: Quality planning}

The first phase is quality planning. Quality planning encompasses the stages of market analysis, curriculum planning and learning programme design and development.

\section{Stage 1: Market analysis}

It appears as if some curriculum development projects take place in a vacuum, without taking cognisance of a proper market analysis (Wolfson 2007). The result is that several qualifications and learning programmes are developed that are indeed interesting to the programme designers, but that do not necessarily fulfill a particular marketneed. A proper market analysis based on real national, regional and international imperatives is thus needed. Such an analysis should identify national and regional knowledge and skills voids identified in legislation, government priorities espoused by national agencies such as the Departments of Labour and Education, and Trade and Industry. Similarly, the market analysis should tap into existing needs identified in national projects such as the Accelerated Shared and Growth Initiative of South Africa (Asgisa), the Joint Initiative for Priority Skills of South Africa (Jipsa) and the National Skills Development Strategy. All these national initiatives have clear implications for higher education. However, extensive stakeholder engagement is needed to ensure a proper market analysis.

\section{Stage 2: Curriculum planning}

If the broader market analysis indicates clear areas of priorities, a more focused curriculum planning process can commence. Curricula should be relevant to the workplace, by addressing clear national and regional workplace and employment imperatives. Additionally, international benchmarking should be done to ensure that learning programmes meet international standards. The concept and liaison with stakeholders are somewhat foreign to education and are associated more with business and organizational studies (Jita 2006). Flowing from stage 1 above, stage 2 requires a focused effort to liaise with a much wider range of stakeholders than would have been the case in the previous educational system. Mitchell, Angle and Wood (1997) proposed a more manageable theory of stakeholder participation, which acknowledges that managers seek a reliable mechanism to separate stakeholders from non-stakeholders and a theory of stakeholder salience which assist to explain 'to whom and to what managers actually pay attention to'. The theory of stakeholder identification and salience by Mitchell et al. (1997) is based on the selection of stakeholders built on the following three attributes:

- Stakeholders' power of influence

- The legitimacy of the stakeholders' claim on the entity and

- The urgency of the stakeholders' claim on the entity.

Table 1 provides a list of multiple stakeholders that should be considered or directly consulted to ensure that curricula meet the needs of the broader society. 
Table 1: An outline of multiple stakeholders for curriculum development

\begin{tabular}{|c|c|c|}
\hline $\begin{array}{l}\text { Stake- } \\
\text { holders }\end{array}$ & Reason for inclusion & References \\
\hline Learners & $\begin{array}{l}\text { Learners are at the centre of OBE curriculum } \\
\text { development as users of education products } \\
\text { and services. }\end{array}$ & $\begin{array}{l}\text { (Van der Merwe and } \\
\text { Joubert 2005; Coladarci } \\
\text { and Kornfield 2007; } \\
\text { Jaschik 2007) }\end{array}$ \\
\hline Alumni & $\begin{array}{l}\text { Past learners have attempted to apply what } \\
\text { they have learnt and should thus know what } \\
\text { works and what does not. }\end{array}$ & (Unisa 2007) \\
\hline Employers & $\begin{array}{l}\text { Providers of employment will know whether } \\
\text { learners have been sufficiently educated to do } \\
\text { the employers' work. Employers present the } \\
\text { view-point of practitioners in the workplace. }\end{array}$ & $\begin{array}{l}\text { (Prahalad 1992; Birkin } \\
\text { 2006; } \\
\text { Wolfson 2007) }\end{array}$ \\
\hline $\begin{array}{l}\text { Government } \\
\text { departments }\end{array}$ & $\begin{array}{l}\text { Higher education programmes also address } \\
\text { government needs, e.g. economic growth, } \\
\text { public services, labour market reform. }\end{array}$ & $\begin{array}{l}\text { (Bitzer 2006; Rasool } \\
\text { 2006; Khanyile 2007) }\end{array}$ \\
\hline $\begin{array}{l}\text { Local } \\
\text { universities }\end{array}$ & $\begin{array}{l}\text { Benchmarking and co-operating with other } \\
\text { universities and sharing lessons and research } \\
\text { projects. Resources may enrich the curriculum. }\end{array}$ & $\begin{array}{l}\text { (Barnett 1992; Msila } \\
\text { 2006) }\end{array}$ \\
\hline $\begin{array}{l}\text { International } \\
\text { universities }\end{array}$ & $\begin{array}{l}\text { Curriculum alignment with global universities } \\
\text { ensures that international best practices and a } \\
\text { global curriculum is created and applied. }\end{array}$ & $\begin{array}{l}\text { (Barnett 2002; Van Wyk } \\
\text { and Tedrow 2004) }\end{array}$ \\
\hline $\begin{array}{l}\text { Consultants } \\
\text { or specialists }\end{array}$ & $\begin{array}{l}\text { Internal and external subject matter experts } \\
\text { may provide specialist knowledge that could } \\
\text { enrich curriculum. }\end{array}$ & (Wolfson 2007) \\
\hline $\begin{array}{l}\text { Mentors and } \\
\text { coaches }\end{array}$ & $\begin{array}{l}\text { Academic, workplace or external mentors } \\
\text { and coaches could share their knowledge } \\
\text { and wisdom and thus contribute to curriculum } \\
\text { development. }\end{array}$ & $\begin{array}{l}\text { (Herman and Mandell } \\
\text { 2006; } \\
\text { Mohono-Mahlatsi and Van } \\
\text { Tonder 2006) }\end{array}$ \\
\hline SETAs & $\begin{array}{l}\text { SETAs know what the major skills priorities are } \\
\text { in their sectors. Higher education could ensure } \\
\text { that these priorities are sufficiently addressed } \\
\text { at both curriculum and programme levels, and } \\
\text { that life-long learning paths are created. }\end{array}$ & $\begin{array}{l}\text { (Lategan 2007; Wolfson } \\
\text { 2007) }\end{array}$ \\
\hline ETQAs & $\begin{array}{l}\text { ETQAs set clear quality criteria that should also } \\
\text { be met by higher education institutions. }\end{array}$ & (Lategan 2007) \\
\hline SAQA & $\begin{array}{l}\text { SAQA provides the overall national quality } \\
\text { standards and registers qualifications that } \\
\text { should meet real national needs. }\end{array}$ & $\begin{array}{l}\text { (Keevy and Blom 2007; } \\
\text { Wolfson 2007) }\end{array}$ \\
\hline
\end{tabular}




\begin{tabular}{|c|c|c|}
\hline $\begin{array}{l}\text { Professional } \\
\text { bodies }\end{array}$ & $\begin{array}{l}\text { These bodies can provide specialist and } \\
\text { professional advice regarding a particular } \\
\text { profession, field or sub-field. }\end{array}$ & (Gouda and Banks 2006) \\
\hline $\begin{array}{l}\text { Advisory } \\
\text { bodies }\end{array}$ & $\begin{array}{l}\text { Having external advisory bodies providing } \\
\text { independent input could play a significant } \\
\text { role to ensure that cutting-edge content is } \\
\text { embedded in curricula. }\end{array}$ & (Barnes and Phillips 2000) \\
\hline Community & $\begin{array}{l}\text { The community and their representative bodies } \\
\text { may have an interest in the outcome of higher } \\
\text { education offerings. }\end{array}$ & $\begin{array}{l}\text { (Reddy, Le Grange and } \\
\text { Waghid 2004; Bitzer } \\
\text { 2006; Rasool 2006) }\end{array}$ \\
\hline $\begin{array}{l}\text { Research } \\
\text { institutions }\end{array}$ & $\begin{array}{l}\text { Private and public research organisations may } \\
\text { possess leading-edge research results that } \\
\text { could inform issues to be addressed in higher } \\
\text { education curricula. }\end{array}$ & (Barnes and Phillips 2000) \\
\hline $\begin{array}{l}\text { Private } \\
\text { providers }\end{array}$ & $\begin{array}{l}\text { Many private providers have developed } \\
\text { good partnerships with private and public } \\
\text { companies and may thus add significant value } \\
\text { in the curriculum development process. }\end{array}$ & (Van Rooyen 2007) \\
\hline $\begin{array}{l}\text { Assessors and } \\
\text { moderators }\end{array}$ & $\begin{array}{l}\text { Assessors and moderators can provide inputs } \\
\text { and feedback that could be used for quality } \\
\text { improvement of curriculum development and } \\
\text { assessment practices. }\end{array}$ & $\begin{array}{l}\text { (Bushney 2005; Ramoroka } \\
\text { 2007; Wolfson 2007) }\end{array}$ \\
\hline Academics & $\begin{array}{l}\text { Academics play a critical role to ensure } \\
\text { that curricula are continuously updated by } \\
\text { using their knowledge of specialized fields of } \\
\text { expertise. }\end{array}$ & $\begin{array}{l}\text { (Kochan 2002; Prahalad } \\
\text { 2002; } \\
\text { Msila 2006; Coladarci } \\
\text { and Kornfield 2007; } \\
\text { Jaschik 2007) }\end{array}$ \\
\hline
\end{tabular}

\section{Stage 3: Learning programme design and development}

Once the inputs have been received from all the stakeholders indicated above, the qualification can be designed and the learning programme developed. The new higher education system embraces an outcomes-based approach to learning programme development. Emphasis should therefore be placed on full outcomes-based alignment of the learning programme, including all learning guides. This stage also includes implementation planning to ensure that design is completed so that the programme will be ready on the particular target date.

\section{Phase B: Quality management system implementation}

The second phase deals with the implementation of the quality management system. Although the quality management system becomes operational during the previous three stages, a significant focus on quality management system implementation is required during the learning programme delivery. 


\section{Stage 4: Programme delivery}

During this stage the programme is delivered. Different modes of delivery can be used, for example, contact delivery (face-to-face), online delivery, distance learning, or blended learning, that is, a combination of different modes (Nel and Dreyer 2005; Van der Spuy and Wöcke 2003). However, a learner support strategy is needed to ensure that high quality learner support is provided when the programme is delivered. Following the example set in the private sector, such a strategy and its associated services need to be maintained by a proper learning management system. The learning management system makes it possible to capture learner records and to track learner progress on different learning programmes and levels on the NQF. Moreover, the effective implementation of a quality management system is dependent on sufficient resource allocation and staff capacity and development at the higher education institution.

\section{Phase C: Quality review}

The last phase focuses on conducting quality reviews to determine the extent to which quality is embedded in higher education programme offerings. This phase will also involve stakeholder engagement with the view of determining whether stakeholder needs have been adequately addressed during programme delivery. Two stages are of utmost importance here:

- Stage 5 (assessment and moderation) is essential to ensure that competent learners exit higher education.

- Stage 6 (programme evaluation) ensures that the overall programme is evaluated to determine its impact, also in the marketplace.

\section{Stage 5: Assessment and moderation}

In most current curriculum development systems, the processes of curriculum development and assessment are treated as separated entities. This model proposes a direct integration of assessment, as well as moderation into the curriculum development framework. Furthermore, the model proposes that integrative assessment be planned when the curriculum is set up. Also, both specific outcomes and critical cross-field outcomes should be clearly embedded in the learning programme, right from the start. By integrating assessment and moderation as part of curriculum development, a better integrated curriculum is established. Assessment criteria should be clearly outlined in learning and assessor guides to enable learners, assessors and moderators to follow a consistent approach to assessment and moderation (Bushney 2005).

\section{Stage 6: Programme evaluation}

Higher education academics do not spend enough time and resources on programme evaluation. Where programmes are evaluated, this is done in a fragmented and uncoordinated manner. Different types of programme evaluation methods can be used as a quality review mechanism: 
- Learner satisfaction surveys (Coladarci and Komfield 2007)

- Employer satisfaction surveys

- Self assessment and self-reflection (Bushney 2005)

- Peer reviews (Berkhout 2006)

- Impact studies, including return on investment

- Through-put rates (Breier and Mabizela 2008)

- Alumni career tracking

- Quality audits (Hendel and Lewis 2005).

Using these evaluation techniques and infusing the results thereof into your quality management system, may play a meaningful role to create a culture of continuous improvement, and ultimately excellence into higher education curriculum development.

\section{CONCLUSION}

This article proposes a multi-stakeholder model to achieve excellence in higher education curriculum development. A total of 18 stakeholders have been identified for this purpose. In essence, a clear process approach is postulated that incorporates the three typical phases of a quality management approach, i.e. quality planning, quality management system implementation and quality review. These phases should be implemented concurrently with the steps of the curriculum development process. First, proper market analysis is needed to infuse market needs identified by all stakeholders. Second, design and development is done in accordance with outcomesbased learning principles. Third, the learning programme is delivered, using a wide variety of delivery mechanisms appropriate to the modern learning market. Proper resource allocation and staff development is of utmost importance during the design and delivery phases of the model. Fourth, an outcomes-based assessment system should be planned and aligned with the curriculum development process. Lastly, it is critical to institute rigorous evaluation methods such as self-assessment, peer assessment and impact studies to measure the effectiveness of curriculum. Thus, the model suggests an integrated approach to curriculum development based on multistakeholder engagement. The end-result is a relevant and market-driven curriculum meeting the needs of all stakeholders.

\section{REFERENCES}

Barnes, N. J. and P. S. Phillips. 2000. Higher education partnerships. International Journal of Sustainability in Higher Education 1 (2): 182-190.

Barnett, C. K. 1992. The global agenda for research and teaching in the 1990s. In Globalizing management: Creating and leading the competitive organization, eds. V. Pucik, N. M. Ticky and C. K. Barnett, 319-339. New York: John Wiley. 
Berkhout, S. 2006. Higher education quality assurance in South Africa widens democracy or not? Response to Anneke Venter. South African Journal of Higher Education 20 (6): 919-923.

Birkin, M. 2006. HR Myopia: It's time for us to question our 30 year old 'people' model. HR Future April:35.

Bitzer, E. M. 2006. Stakeholders in quality: A response to Loyiso Jita's article. South African Journal of Higher Education 20 (6): 932-940.

Breier, M. and M. Mabizela. 2008. Higher education. In Human resources development review 2008: Education, employment and skills in South Africa, eds. A. Kraak and K. Press, 278-299. Cape Town: HSRC Press.

Bushney, M. 2005. An assessment framework for human resource management in specific higher education institutions. D.Phil. thesis, University of Johannesburg.

Coladarci, T. and I. Komfield. 2007. Rate MyProfessors.com versus formal in-class student evaluations of teaching. Practical Assessment, Research and Evaluation 12 (6): 1-14.

Csikszentmihalyi, M. 2003. Good business: Leadership, flow, and the making of meaning. London: Penguin.

Gouda, A. and F. Banks. 2006. The impact of professional dignity on the development of teacher knowledge. Progressio 28 (1-2): 96-109.

Guri, S. 1986. Equality and excellence in higher education - Is it possible? A case of Everyman's University, Israel. Higher Education 15:59-71.

Harvey, L. and D. Green, 1993. Defining quality, assessment and evaluation. Higher Education 18 (1): 1-24.

Hendell, D. D. and D. R. Lewis. 2005. Quality assurance of higher education in transition countries: Accreditation - accountability and assessment. Tertiary Education and Management 11:239-258.

Herman, L. and A. Mandell. 2006. Wonderful bewilderment: In praise of knowing that one does not know. Progressio 28 (1-2): 6-16.

Jaschik, S. 2007. Could RateMyProfessors.com be Right? Inside Higher Education June: $1-2$.

Jita, L. C. 2006. Theorizing stakeholder participation within the higher education quality assurance system in South Africa. South African Journal of Higher Education 20 (6): 924-931.

Keevy, J. and R. Blom. 2007. The integration of education and training in a comprehensive linked National Qualifications Framework: A critical reflection on recent developments in South Africa. Paper presented at the All Africa IVETA Regional IFTDO ASTD Conference, 13 May, Mauritius.

Khanyile, S. 2007. Benefits of growth not shared, says indaba. The Star Business Report 200723 May:21.

Kochan, T. A. 2002. Addressing the crisis in confidence in corporations: Root causes, victims, and strategies for reform. Academy of Management Executive 16 (3): 139-141.

Lategan, A. 2007. HRD legislation. In Managing Human Resource Development: An outcomes-based approach, ed. M. Meyer, 13-56. Durban: LexisNexis-Butterworths.

Mitchell, R. K., B. K. Angle and D. J. Wood. 1997. Toward a theory of stakeholder participation and salience: Defining the principle of who and what really counts. Academy of Management Review 22 (4): 853-886. 
Mohono-Mahlatsi, L. and F. van Tonder. 2006. The effectiveness of mentoring in the distance teacher education programmes at the Lesotho College of Education: Student teachers' and tutors' perceptions. South African Journal of Education 26 (3): 383-396.

Msila, F. 2006. Massification: Preparing faculty for open learning systems. Progressio 28 (1-2): 82-95.

Munson, C. E. 1994. Characteristics of excellence in Social Work Education. Journal of Social Work Education 30 (1): 1-9.

Nel, C. and C. Dreyer. 2005. Factors predicting English second-language students' use of web-based information systems: Implications for student support. South African Journal of Higher Education 19 (1): 129-143.

Peters, T. J. and R. H. Waterman. 1982. In search of excellence: Lessons from America's best-run companies. New York: Harper and Row.

Ramoroka, N. J. 2007. Educators' understanding of the premises underpinning outcomesbased education and its impact on their classroom assessment practices. M.Ed. dissertation. University of Pretoria.

Rasool, H. 2006. Rag trade needs a fine fit of complex skills. The Star 2006. 7 June:2.

Reddy, C., L. le Grange and Y. Waghid. 2004. Environment (education) as a community project: deliberative democracy in action. South African Journal of Higher Education 18 (1): 111-126.

Savitz, A. W. and K. Weber. 2006. The triple bottom line: How today's Bestrun companies are achieving economic, social and environmental success. San Francisco: Jossey-Bass.

SAEF see South African Excellence Foundation.

South African Excellence Foundation. 2000. Excellence awards: Application instructions and forms. Pretoria: South African Excellence Foundation.

Unisa see University of South Africa.

University of South Africa. 2007. Self-evaluation portfolio for the Commonwealth of Learning trail audit. Pretoria: University of South Africa Press.

Van der Merwe, L. J. and G. Joubert. 2005. University of the Free State allied health professions students' expectations and experience of an undergraduate physiology course. South African Journal of Higher Education 19 (2): 306-315.

Van der Spuy, M. and A. Wöcke. 2003. The effectiveness of technology based (interactive) distance learning methods in a large South African financial services organization. South African Journal of Business Management 34 (2): 1-11.

Van Rooyen, M. 2007. Professionalisation of HRD: A private provider perspective. Paper delivered at Knowledge Resources/SABPP seminar. Kyalami, 6 June.

Van Wyk, C. and B. Tedrow. 2004. Perceptions of staff at Eastern Cape Technikon on the value and effectiveness of international linkeage partnerships. South African Journal of Higher Education 18 (1): 165-184.

Venter, A. 2006. Student involvement and empowerment in quality assurance in distance education in South Africa. South African Journal of Higher Education 20 (6): 910-918.

Wheeler, D. and M. Sillanpaa. 1997. The stakeholder corporation: A blueprint for maximizing stakeholder value. London: Pitman.

Wolfson, R. 2007. Training needs analysis. In Managing human resource development: An outcomes-based approach, ed. M. Meyer, 113-136. Durban: LexisNexis-Butterworths. 